\title{
Effect of Salicylic Acid on growth and yield of Onion (Allium cepa L.)
}

\author{
S. B. Nangare*, S. D. Gaikwad, S. S. Dighe and M. B. Khamkar \\ Scheme for Research on Onion Storage, Department of Horticulture, MPKV, \\ Rahuri-413 722, Maharashtra, India \\ *Corresponding author
}

\section{Keywords}

Onion, vegetative growth, chlorophyll, salicylic acid, yield

Article Info

Accepted:

25 April 2017

Available Online:

10 June 2018

\section{A B S T R A C T}

The field experiment was carried out at Scheme for Research on Onion Storage, Department of Horticulture, Mahatma Phule krishi Vidyapeeth, Rahuri during the rabi season of 2015-16 to study the effect of salicylic acid on onion (Allium cepa L.) cv. N-2-41. The experiment was laid out in a Factorial Randomized block design with two replications consisting two factors, Factor-A (03) with levels of concentration and water spray and Factor-B (07) with seven levels of time of applications. The result indicated that, there was significant influence of foliar application of salicylic acid on growth parameters viz., plant height $(68.28-76.45 \mathrm{~cm})$, number of leaves per plant $(13.15-15.30)$, neck thickness (0.84-1.07) and higher level of chlorophyll content (0.58-0.75 mg $100 \mathrm{~g}-{ }^{1}$ f.w) as compare to water spray. The foliar application of salicylic acid at lower concentration (100 $\mathrm{mg} / \mathrm{l}$ ) gives significantly maximum plant height, number of leaves per plant, total chlorophyll content, bulb diameter, average weight of bulb, total bulb yield, marketable bulb yield as compare to higher dose $(150 \mathrm{mg} / \mathrm{l})$ and water spray. Three foliar sprays at 30 , 45 and 60 DAT were beneficial for vegetative growth, yield, quality and storability of onion cv. N 2-4-1 than either single or two sprays of salicylic acid.

\section{Introduction}

Onion (Allium cepa L.) is being extensively cultivated all over the world. India is the $2^{\text {nd }}$ largest producer of onion, in the world next only to China but the productivity of onion in India is very low. It occupies an area of 12.03 lakh ha, with production lakh tonnes. The export of onion during 2013-14 was 14.82 lakh MT with a value of Rs 316.961 crores (Anon. 2014). As far as onion production per hectare is concerned, improved and modern agronomic practices and application of Plant Growth Regulators (PGRs) might be useful in increasing onion production. In recent years, salicylic acid has been the focus of intense research due to its function as an endogenous signal mediating local and systemic plant defense responses against pathogens.

Salicylic acid (SA) is a phenolic phytohormone that acts as a key regulator of the signaling network in plants under abiotic and biotic stresses. Salicylic acid exerts stimulatory effects on various physiological processes related to plant growth and development. The purpose of this study was to test the hypothesis that exogenous application 
of SA affects positively the growth, quality and yield. Salicylic acid $\left(\mathrm{C}_{7} \mathrm{H}_{6} \mathrm{O}_{3}\right)$ discovered as one of the important phenolic compounds in plants (Chandra et al., 2007).

This substance naturally is produced in plants in very low amounts. Various physiological and biochemical effects of salicylic acid on plant systems have been documented (Raskin, 1992). Salicylic acid treatment increases or decreases chlorophyll content, depending on the genotype (Chandra and Bhatt 1998). Salicylic acid a natural molecule plays an important role in regulating a number of physiological processes in plants. Its exogenous application has promoted plant performance under biotic and abiotic stresses (Senaratna et al., 2000). Foliar spray of low concentration of salicylic acid promote and influence the growth, development, differentiation of cells, and tissues of plants and enhanced the plant's growth parameters (Helgi and Rolfe 2005).

Considering the above facts, the present investigation entitled "Effect of salicylic acid on onion (Allium cepa L.)" was planned to test the effect of salicylic acid as a foliar spray at different time of applications

\section{Materials and Methods}

The present trial entitled "Effect of salicylic acid on onion (Allium cepa L.)" was carried out at Scheme for Research on Onion Storage, Department of Horticulture, Mahatma Phule krishi Vidyapeeth, Rahuri, during rabi season of 2015-16. The topography of the field was fairly leveled flat beds were prepared for onion transplanting, soil was medium black having moderate in moisture retention capacity. Climatically, this area is in semiarid, sub-tropical zone, with annual average rainfall $475 \mathrm{~mm}$. The annual mean maximum and minimum temperature are $35.83^{\circ}$ and $17.82^{\circ}$, respectively during the period of experimentation. The onion seed was sown in raised beds in nursery for seedling preparation. Main field was prepared to fine tilth and flat beds of $3 \times 2 \mathrm{~m}$ were prepared. At the time of land preparation experimental site was applied manure and fertilizers as recommended. The healthy seedlings of onion were transplanted on $12^{\text {th }}$ January, 2015 with spacing of $15 \times 10 \mathrm{~cm}$.

Weeding was done manually throughout the growing season. The crop was harvested on $2^{\text {nd }}$ May, 2016. At harvest the growth parameters like plant height, number of leaves and neck thickness observed from ten randomly selected plants and observations recorded. After harvesting of bulb different size bulb, A grade $(>60 \mathrm{~mm}), \mathrm{B}$ grade $(40-60$ $\mathrm{mm}$ ) and $\mathrm{C}$ grade $(<40 \mathrm{~mm})$ were selected and their percentage were computed on weight basis. Total bulb yield ( $\mathrm{q} \mathrm{ha}^{-1}$ ) and marketable bulb (\%) were calculated. The data recorded for each observation in this present investigation was analyzed statistically as per the procedure described by Panse and Sukhatme (1989).

\section{Results and Discussion}

\section{Growth parameters}

\section{Plant height (cm)}

It was revealed that the differences in mean plant height due to salicylic acid treatments were observed to be statistically significant and presented in Table 1.The balance of internal level of natural auxins due to salicylic acid is mainly responsible for maintaining physiological activities in the plant system and that significantly resulted into better growth and more plant height.

Among the conc. of salicylic acid, $\mathrm{A}_{1}$ recorded maximum plant height $(73.73 \mathrm{~cm})$ which was significantly superior over $\mathrm{A}_{2}$ and $\mathrm{A}_{3}$. The time 
of application effect was non-significant. The interactions effects were non-significant, however the combination $\mathrm{A}_{1} \mathrm{~B}_{7}\left(\mathrm{~T}_{7}\right)$ recorded the maximum plant height $(76.45 \mathrm{~cm})$ and the combination $\mathrm{A}_{3} \mathrm{~B}_{2}\left(\mathrm{~T}_{16}\right)$ recorded minimum plant height $(62.97 \mathrm{~cm})$.

\section{Number of leaves per plant}

The data pertaining to number of leaves per plant as influenced by different salicylic acid treatments and time of application was recorded at harvest and presented in Table 1. It was revealed that the differences in mean number of leaves per plant due to salicylic acid treatments were observed to be statistically significant. The exogenous application of SA had effect on increased photosynthetic activity and cell division which enhances the number of leaves per plant (Gharib, 2006).

Among the conc. of salicylic acid, $\mathrm{A}_{1}$ recorded maximum number of leaves per plant (14.61) which were significantly superior to $A_{2}$ and $A_{3}$ treatments. The time of application effects were non-significant. With respect to interactions effect were non-significant, however the combination $\mathrm{A}_{1} \mathrm{~B}_{7}\left(\mathrm{~T}_{7}\right)$ recorded the maximum number of leaves per plant (15.30) and the combination $\mathrm{A}_{3} \mathrm{~B}_{4} \quad\left(\mathrm{~T}_{18}\right)$ recorded minimum number of leaves per plant (11.64).

These findings are close relevant with the result of Jain and Srivastava (1981) in maize, Gutierrez-Coronado et al., (1998) in soyabean, Pankaj and Sharma (2003) in okra, Amin et al., (2007) in onion, Jeyakumar et al., (2008) in black gram, Pradhan et al., (2016) and Prajapati et al., (2016) in onion.

\section{Neck thickness $(\mathrm{cm})$}

It was revealed that the differences in mean neck thickness of plant due to salicylic acid treatments were observed to be statistically significant and results are presented in Table 1. Neck thickness of onion is important parameter since it is the neck which is ultimately going to be converted into bulb. Hence, more the neck thickness more will be size of bulb and yield (Shashikumar and Shashidhar, 2015). Neck thickness rapidly reduced 90 days after transplanting in onion due to maturity.

Among the conc. of salicylic acid, $\mathrm{A}_{3}$ recorded minimum neck thickness $(0.75 \mathrm{~cm})$ which was significantly higher than $\mathrm{A}_{1}$ and $\mathrm{A}_{2}$ treatments. With respect to time of applications effect was non-significant. The interactions effect were non-significant, however the combination $\mathrm{A}_{3} \mathrm{~B}_{5}\left(\mathrm{~T}_{19}\right)$ recorded minimum neck thickness $(0.71 \mathrm{~cm})$. The combination $\mathrm{A}_{1} \mathrm{~B}_{7} \quad\left(\mathrm{~T}_{7}\right)$ recorded the maximum neck thickness (1.07 $\mathrm{cm})$. The result obtained are in close agreement with the observation recorded by Sakhabutdinova et al., (2003) in wheat, Pankaj and Sharma (2003) in okra, Amin et al., (2007), Pradhan et al., (2016), Prajapati et al., (2016) in onion.

\section{Yield and yield contributing characters}

The data pertaining to yield contributing characters viz., polar and equatorial diameter, average weight of bulb (g) and grades of bulbs (\%) was recorded during the present investigation and result data presented in Table 2.

\section{Polar diameter $(\mathrm{cm})$}

Among SA conc., the maximum polar diameter of bulb $(4.82 \mathrm{~cm})$ recorded in $A_{1}$ which was significantly higher than $\mathrm{A}_{2}$ and $\mathrm{A}_{3}$. Among the time of application effect was nonsignificant, however the maximum polar diameter of bulb $(4.63 \mathrm{~cm})$ was recorded in $\mathrm{B}_{7}$. However, the minimum polar diameter of bulb $(4.48 \mathrm{~cm})$ was recorded in $\mathrm{B}_{1}$. 
Table.1 Effect of salicylic acid concentrations and time of applications on plant height $(\mathrm{cm})$, number of leaves, neck thickness $(\mathrm{cm})$

\begin{tabular}{|c|c|c|c|c|c|c|}
\hline Treatment & \multicolumn{2}{|c|}{ Plant height(cm) } & Numb & of leaves & \multicolumn{2}{|c|}{ Neck thickness (cm) } \\
\hline \multicolumn{7}{|l|}{ Factor A } \\
\hline $\mathbf{A}_{1}$ & \multicolumn{2}{|c|}{73.73} & \multicolumn{2}{|c|}{14.61} & \multicolumn{2}{|c|}{0.99} \\
\hline $\mathbf{A}_{2}$ & \multicolumn{2}{|c|}{70.37} & & 3.56 & \multicolumn{2}{|c|}{0.92} \\
\hline $\mathbf{A}_{3}$ & \multicolumn{2}{|c|}{65.42} & & 2.04 & \multicolumn{2}{|c|}{0.75} \\
\hline \multicolumn{7}{|l|}{ Factor B } \\
\hline $\mathbf{B}_{1}$ & \multicolumn{2}{|c|}{70.09} & & 3.25 & \multicolumn{2}{|c|}{0.85} \\
\hline$\underline{B_{2}}$ & \multicolumn{2}{|c|}{68.66} & & 3.38 & \multicolumn{2}{|c|}{0.87} \\
\hline$\underline{B_{3}}$ & \multicolumn{2}{|c|}{69.31} & & 3.42 & \multicolumn{2}{|c|}{0.90} \\
\hline $\mathbf{B}_{4}$ & \multicolumn{2}{|c|}{69.87} & & 3.15 & \multicolumn{2}{|c|}{0.91} \\
\hline $\mathbf{B}_{5}$ & \multicolumn{2}{|c|}{70.57} & & 3.58 & \multicolumn{2}{|c|}{0.87} \\
\hline $\mathbf{B}_{6}$ & \multicolumn{2}{|c|}{70.08} & & 3.52 & \multicolumn{2}{|c|}{0.88} \\
\hline $\mathbf{B}_{7}$ & \multicolumn{2}{|c|}{70.29} & & 3.53 & \multicolumn{2}{|c|}{0.92} \\
\hline \multicolumn{7}{|l|}{ Interaction } \\
\hline $\mathbf{A}_{1} \mathbf{B}_{1}$ & & & & 3.95 & & \\
\hline $\mathbf{A}_{1} \mathbf{B}_{2}$ & & & & 4.10 & & \\
\hline$A_{1} B_{3}$ & & & & 4.70 & & \\
\hline $\mathbf{A}_{1} \mathbf{B}_{4}$ & & & & 4.10 & & \\
\hline$A_{1} B_{5}$ & & & & 4.85 & & \\
\hline $\mathbf{A}_{1} \mathbf{B}_{6}$ & & & & 5.25 & & \\
\hline $\mathbf{A}_{1} \mathbf{B}_{7}$ & & & & 5.30 & & \\
\hline $\mathbf{A}_{2} \mathbf{B}_{1}$ & & & & 3.70 & & \\
\hline $\mathbf{A}_{2} \mathbf{B}_{2}$ & & & & 3.85 & & \\
\hline $\mathbf{A}_{2} \mathbf{B}_{3}$ & & & & 3.70 & & \\
\hline $\mathbf{A}_{2} \mathbf{B}_{4}$ & & & & 3.70 & & \\
\hline $\mathbf{A}_{2} \mathbf{B}_{5}$ & & & & 3.65 & & \\
\hline $\mathbf{A}_{2} \mathbf{B}_{6}$ & & & & 3.15 & & \\
\hline $\mathbf{A}_{2} \mathbf{B}_{7}$ & & & & 3.20 & & \\
\hline$A_{3} \mathbf{B}_{1}$ & & & & 2.10 & & \\
\hline $\mathbf{A}_{3} \mathbf{B}_{2}$ & & & & 2.20 & & \\
\hline $\mathbf{A}_{3} \mathbf{B}_{3}$ & & & & 1.85 & & \\
\hline $\mathbf{A}_{3} \mathbf{B}_{4}$ & & & & 1.64 & & \\
\hline $\mathbf{A}_{3} \mathbf{B}_{5}$ & & & & 2.26 & & \\
\hline $\mathbf{A}_{3} \mathbf{B}_{6}$ & & & & 2.15 & & \\
\hline $\mathbf{A}_{3} \mathbf{B}_{7}$ & & & & 2.10 & & \\
\hline & S.E. \pm & $\mathrm{CD}$ at $5 \%$ & S.E. \pm & $\mathrm{CD}$ at $5 \%$ & S.E. \pm & $\begin{array}{c}\text { CD at } 5 \\
\%\end{array}$ \\
\hline Factor A & 0.51 & 1.52 & 0.11 & 0.34 & 0.012 & 0.037 \\
\hline Factor B & 0.79 & NS & 0.18 & NS & 0.019 & NS \\
\hline Interaction & 1.37 & NS & 0.31 & NS & 0.033 & NS \\
\hline
\end{tabular}


Table.2 Effect of salicylic acid concentrations and time of applications on polar diameter $(\mathrm{cm})$, equatorial diameter $(\mathrm{cm})$ and average weight of bulb $(\mathrm{g})$

\begin{tabular}{|c|c|c|c|}
\hline Treatment & Polar diameter (cm) & $\begin{array}{c}\text { Equatorial } \\
\text { diameter }(\mathbf{c m})\end{array}$ & A verage weight of bulb(g) \\
\hline \multicolumn{4}{|l|}{ Factor A } \\
\hline$\overline{\mathbf{A}_{1}}$ & 4.82 & 5.62 & 81.74 \\
\hline $\mathbf{A}_{2}$ & 4.56 & 5.32 & 77.80 \\
\hline$\overline{\mathbf{A}_{3}}$ & 4.23 & 4.91 & 73.07 \\
\hline \multicolumn{4}{|l|}{ Factor B } \\
\hline $\mathbf{B}_{1}$ & 4.48 & 5.22 & 76.68 \\
\hline$\overline{\mathbf{B}_{2}}$ & 4.50 & 5.24 & 76.88 \\
\hline $\mathbf{B}_{\mathbf{3}}$ & 4.51 & 5.25 & 76.99 \\
\hline $\mathbf{B}_{4}$ & 4.55 & 5.30 & 77.62 \\
\hline $\mathbf{B}_{5}$ & 4.52 & 5.29 & 77.42 \\
\hline $\mathbf{B}_{6}$ & 4.55 & 5.32 & 77.86 \\
\hline $\mathbf{B}_{7}$ & 4.63 & 5.39 & 79.30 \\
\hline \multicolumn{4}{|l|}{ Interaction } \\
\hline $\mathbf{A}_{1} \mathbf{B}_{1}$ & 4.61 & 5.38 & 78.52 \\
\hline $\mathbf{A}_{1} \mathbf{B}_{2}$ & 4.65 & 5.42 & 78.98 \\
\hline $\mathbf{A}_{\mathbf{1}} \mathbf{B}_{\mathbf{3}}$ & 4.86 & 5.65 & 81.76 \\
\hline $\mathbf{A}_{1} \mathbf{B}_{4}$ & 4.90 & 5.69 & 82.32 \\
\hline $\mathbf{A}_{1} \mathbf{B}_{5}$ & 4.86 & 5.71 & 82.48 \\
\hline $\mathbf{A}_{1} \mathbf{B}_{6}$ & 4.86 & 5.67 & 81.98 \\
\hline $\mathbf{A}_{1} \mathbf{B}_{7}$ & 5.02 & 5.85 & 86.16 \\
\hline $\mathbf{A}_{2} \mathbf{B}_{1}$ & 4.49 & 5.23 & 76.78 \\
\hline $\mathbf{A}_{2} \mathbf{B}_{2}$ & 4.47 & 5.20 & 76.43 \\
\hline $\mathbf{A}_{2} \mathbf{B}_{3}$ & 4.55 & 5.28 & 77.42 \\
\hline $\mathbf{A}_{2} \mathbf{B}_{4}$ & 4.55 & 5.31 & 77.66 \\
\hline $\mathbf{A}_{2} \mathbf{B}_{5}$ & 4.52 & 5.30 & 77.55 \\
\hline $\mathbf{A}_{2} \mathbf{B}_{6}$ & 4.65 & 5.43 & 79.15 \\
\hline $\mathbf{A}_{2} \mathbf{B}_{7}$ & 4.67 & 5.46 & 79.58 \\
\hline $\mathbf{A}_{3} \mathbf{B}_{1}$ & 4.35 & 5.06 & 74.75 \\
\hline $\mathbf{A}_{3} \mathbf{B}_{2}$ & 4.38 & 5.10 & 75.22 \\
\hline $\mathbf{A}_{\mathbf{3}} \mathbf{B}_{\mathbf{3}}$ & 4.12 & 4.81 & 71.78 \\
\hline $\mathbf{A}_{3} \mathbf{B}_{4}$ & 4.20 & 4.91 & 72.87 \\
\hline $\mathbf{A}_{3} \mathbf{B}_{5}$ & 4.18 & 4.85 & 72.23 \\
\hline$\overline{A_{3} B_{6}}$ & 4.16 & 4.87 & 72.44 \\
\hline \multirow[t]{2}{*}{$\mathbf{A}_{3} \mathbf{B}_{7}$} & 4.21 & 4.85 & 72.17 \\
\hline & $\mathrm{CD}$ at $5 \%$ & $\mathrm{CD}$ at $5 \%$ & CD at $5 \%$ \\
\hline Factor A & 0.02 & $0.0 \overline{3}$ & 0.43 \\
\hline Factor B & 0.03 & 0.04 & 0.66 \\
\hline Interaction & 0.06 & 0.08 & 1.14 \\
\hline
\end{tabular}


Table.3 Effect of salicylic acid concentrations and time of applications on total bulb yield and marketable bulb (\%)

\begin{tabular}{|c|c|c|c|c|c|c|}
\hline Treatment & Total b & d (kg plot & \multicolumn{2}{|c|}{ Total bulb yield $\left(\mathrm{qha}^{-1}\right)$} & \multicolumn{2}{|c|}{ Marketable bulb (\%) } \\
\hline \multicolumn{7}{|l|}{ Factor A } \\
\hline$A_{1}$ & \multicolumn{2}{|c|}{27.95} & \multicolumn{2}{|c|}{463.01} & \multicolumn{2}{|c|}{93.24} \\
\hline $\mathbf{A}_{2}$ & \multicolumn{2}{|c|}{27.10} & \multicolumn{2}{|c|}{384.01} & \multicolumn{2}{|c|}{90.17} \\
\hline $\mathbf{A}_{\mathbf{3}}$ & \multirow{2}{*}{\multicolumn{2}{|c|}{19.69}} & \multicolumn{2}{|c|}{318.82} & \multicolumn{2}{|c|}{87.24} \\
\hline \multicolumn{6}{|l|}{ Factor B } & \\
\hline $\mathrm{B}_{1}$ & \multicolumn{2}{|c|}{24.91} & \multicolumn{2}{|c|}{413.55} & \multicolumn{2}{|c|}{92.33} \\
\hline$B_{2}$ & \multicolumn{2}{|c|}{24.54} & \multicolumn{2}{|c|}{407.34} & \multicolumn{2}{|c|}{90.22} \\
\hline$B_{3}$ & \multicolumn{2}{|c|}{21.98} & \multicolumn{2}{|c|}{364.79} & \multicolumn{2}{|c|}{89.21} \\
\hline $\mathbf{B}_{4}$ & \multicolumn{2}{|c|}{23.19} & \multicolumn{2}{|c|}{384.98} & \multicolumn{2}{|c|}{89.49} \\
\hline $\mathrm{B}_{5}$ & \multicolumn{2}{|c|}{23.07} & & .95 & & \\
\hline $\mathrm{B}_{6}$ & & & & .71 & & \\
\hline $\mathbf{B}_{7}$ & & & & .00 & & \\
\hline Interaction & & & & & & \\
\hline $\mathbf{A}_{1} \mathbf{B}_{1}$ & & & & .00 & & \\
\hline $\mathbf{A}_{1} \mathbf{B}_{2}$ & & & & .35 & & \\
\hline $\mathbf{A}_{1} \mathbf{B}_{\mathbf{3}}$ & & & & .79 & & \\
\hline $\mathbf{A}_{1} \mathbf{B}_{4}$ & & & & .51 & & \\
\hline$A_{1} B_{5}$ & & & & .42 & & \\
\hline$A_{1} B_{6}$ & & & & .75 & & \\
\hline$A_{1} B_{7}$ & & & & .27 & & \\
\hline$A_{2} B_{1}$ & & & & .78 & & \\
\hline$A_{2} B_{2}$ & & & & .34 & & \\
\hline $\mathbf{A}_{2} \mathbf{B}_{3}$ & & & & .82 & & \\
\hline $\mathbf{A}_{2} \mathbf{B}_{4}$ & & & & .98 & & \\
\hline $\mathbf{A}_{2} \mathbf{B}_{5}$ & & & & .13 & & \\
\hline $\mathbf{A}_{2} \mathbf{B}_{6}$ & & & & .56 & & \\
\hline $\mathbf{A}_{2} \mathbf{B}_{7}$ & & & & 47 & & \\
\hline$A_{3} B_{1}$ & & & & .87 & & \\
\hline $\mathbf{A}_{3} \mathbf{B}_{2}$ & & & & & & \\
\hline $\mathbf{A}_{3} \mathbf{B}_{3}$ & & & & .76 & & \\
\hline $\mathbf{A}_{3} \mathbf{B}_{4}$ & & & & .44 & & \\
\hline $\mathbf{A}_{3} \mathbf{B}_{5}$ & & & & .29 & & \\
\hline $\mathbf{A}_{3} \mathbf{B}_{6}$ & & & & .81 & & \\
\hline $\mathbf{A}_{3} \mathbf{B}_{7}$ & & & & .27 & & \\
\hline & S.E. \pm & $\mathrm{CD}$ at $5 \%$ & S.E. \pm & $\mathrm{CD}$ at $5 \%$ & S.E. \pm & CD at $5 \%$ \\
\hline Factor A & 0.29 & 0.85 & 4.82 & 14.18 & 0.50 & 1.47 \\
\hline Factor B & 0.44 & 1.30 & 7.36 & 21.67 & 0.76 & $\overline{N S}$ \\
\hline Interaction & 0.76 & 2.26 & 12.7 & 37.54 & 1.32 & NS \\
\hline
\end{tabular}




\section{Treatment details}

Factor A - concentration of salicylic acid and water spray (03)

\begin{tabular}{|c|c|c|}
\hline 1 & & Salicylic acid@100.mg/l \\
\hline 2 & & Salicylic acid@150mg/l \\
\hline 3 & & Water spray \\
\hline \multicolumn{3}{|c|}{ Factor B - Stages of application (07) } \\
\hline 1 & : & $2^{\text {nd }}$ spray at 30 days after transplanting(DAT) \\
\hline 2 & : & $2^{\text {nd }}$ spray at 45 DAT \\
\hline 3 & : & $2^{\text {nd }}$ spray at $60 \mathrm{DAT}$ \\
\hline 4 & : & $2^{\text {nd }}$ spray at $30 \mathrm{DAT}$ and $3^{\text {rd }}$ spray at $45 \mathrm{DAT}$ \\
\hline 5 & : & $2^{\text {nd }}$ spray at $30 \mathrm{DAT}$ and $3^{\text {rd }}$ spray at $60 \mathrm{DAT}$ \\
\hline$\overline{6}$ & & $2^{\text {nd }}$ spray at $45 \mathrm{DAT}$ and $3^{\text {rd }}$ spray at $60 \mathrm{DAT}$ \\
\hline 7 & & $2^{\text {nd }}$ spray at $30 \mathrm{DAT}$ and $3^{\text {rd }}$ spray at $45 \mathrm{DAT}$ and $4^{\text {th }}$ spray at $60 \mathrm{DAT}$ \\
\hline
\end{tabular}

Note: $1^{\text {st }}$ spray of salicylic acid @ $250 \mathrm{mg} / \mathrm{l}$ was given at 30 days after sowing at nursery stage common for all treatments, except water spray treatments.

The interaction effect were significant, however the combination $\mathrm{A}_{1} \mathrm{~B}_{7}\left(\mathrm{~T}_{7}\right)$ recorded the maximum polar diameter of bulb $(5.02$ $\mathrm{cm})$ was at par with the combination $\mathrm{A}_{1} \mathrm{~B}_{4}$ $\left(\mathrm{T}_{4}\right)(4.90 \mathrm{~cm}), \mathrm{A}_{1} \mathrm{~B}_{3}\left(\mathrm{~T}_{3}\right),(4.86 \mathrm{~cm}), \mathrm{A}_{1} \mathrm{~B}_{5}$ $\left(\mathrm{T}_{5}\right)(4.86 \mathrm{~cm}) \mathrm{A}_{1} \mathrm{~B}_{6}\left(\mathrm{~T}_{6}\right)(4.86 \mathrm{~cm})$. Thus resulting higher values of polar diameter in onion bulbs similar findings reported by Ibrahim and Sanna (2005), Amin et al., (2007), Prajapati et al., (2016) and Pradhan et al., (2016) in onion and Bideshki Arvin (2010) in garlic.

\section{Equatorial diameter (cm)}

With respect to the concentrations of salicylic acid, the maximum equatorial diameter of bulb $(5.62 \mathrm{~cm})$ recorded in $A_{1}$ which was significantly superior to $A_{2}$ and $A_{3}$ treatments. Among the time of application effect was non-significant.

The interaction effect were significant, however the combination $\mathrm{A}_{1} \mathrm{~B}_{7}\left(\mathrm{~T}_{7}\right)$ recorded the maximum equatorial diameter of bulb $(5.85 \mathrm{~cm})$ was at par with the combination $\mathrm{A}_{1} \mathrm{~B}_{5}\left(\mathrm{~T}_{5}\right)(5.71 \mathrm{~cm}), \mathrm{A}_{1} \mathrm{~B}_{4}\left(\mathrm{~T}_{4}\right)(5.69 \mathrm{~cm})$, $\mathrm{A}_{1} \mathrm{~B}_{6}\left(\mathrm{~T}_{6}\right)(5.67 \mathrm{~cm})$ and $\mathrm{A}_{1} \mathrm{~B}_{3}\left(\mathrm{~T}_{3}\right)(5.65 \mathrm{~cm})$.
These findings are close agreement with Amin et al., (2007) in onion and Bideshki and Arvin (2010) in garlic and Prajapati et al., (2016) and Pradhan et al., (2016) in onion Meena et al., (2016) in garlic.

\section{Average weight of bulb (g)}

It was revealed that the differences in mean average weight of bulbs due to salicylic acid treatments were observed to be statistically significant.

Considering the conc. of salicylic acid the maximum average weight of bulb $(81.74 \mathrm{~g})$ recorded in $A_{1}$ which was significantly superior over $A_{2}$ and $A_{3}$ treatments. The interaction effects were significant, however the combination $\mathrm{A}_{1} \mathrm{~B}_{7}$ recorded the maximum average weight of bulb $(86.16 \mathrm{~g})$ significantly. These results are in close agreement with Amin et al., (2007), Pradhan et al., (2016) and Prajapati et al., (2016) in onion.

\section{Total bulb yield $\left(\mathrm{kg} \mathrm{plot}^{-1}\right)$}

The data regarding to total bulb yield per plot 
as influenced by different salicylic acid treatments and time of application and presented in Table 3. It is revealed that the differences in regard of total bulb yield due to various treatments of salicylic acid were observed to be statistically significant. Considering the concentration of salicylic acid effects was significant and the highest total bulb yield (27.95 kg plot $\left.{ }^{-1}\right)$ was recorded in which was at par with $\mathrm{A}_{2}\left(27.10 \mathrm{~kg} \mathrm{plot}^{-1}\right)$. Among the time of application, the maximum total bulb yield $\mathrm{kg} \operatorname{plot}^{-1}\left(24.91 \mathrm{~kg} \mathrm{plot}^{-1}\right)$ was recorded in $B_{1}$ which was significantly superior to all the remaining except $\mathrm{B}_{2}(24.54$ $\mathrm{kg}$ plot $\left.^{-1}\right)$ and $\mathrm{B}_{7}\left(24.10 \mathrm{~kg} \mathrm{plot}^{-1}\right)$ which was at par with it. With respect to interactions, the combination $\mathrm{A}_{1} \mathrm{~B}_{7} \quad\left(\mathrm{~T}_{7}\right)$ recorded the maximum total bulb yield $\left(29.72 \mathrm{~kg}\right.$ plot $\left.^{-1}\right)$ was at par with $\mathrm{A}_{1} \mathrm{~B}_{5}\left(\mathrm{~T}_{5}\right)\left(28.88 \mathrm{~kg}^{-1}\right.$ plot $\left.^{-1}\right)$, $\mathrm{A}_{1} \mathrm{~B}_{3}\left(\mathrm{~T}_{3}\right)\left(28.00 \mathrm{~kg} \mathrm{plot}^{-1}\right), \mathrm{A}_{1} \mathrm{~B}_{4}\left(\mathrm{~T}_{4}\right)(27.98$ $\mathrm{kg}$ plot $\left.^{-1}\right)$ and $\mathrm{A}_{1} \mathrm{~B}_{1}\left(\mathrm{~T}_{1}\right)\left(27.95 \mathrm{~kg} \mathrm{plot}^{-1}\right)$. These findings are closely related with Ibrahim and Sanaa (2005) in onion, Amin et al., (2007) in onion, Yildirim and Dursun (2009) in tomato, Bideshki and Arvin (2010) and Meena et al., (2016) in garlic, Prajapati et al., (2016) and Pradhan et al., (2016) in onion.

\section{Marketable bulb (\%)}

The data regarding to marketable bulb (\%) as influenced by different salicylic acid treatments and time of application are presented in Table 3.

Considering the concentrations of salicylic acid, effect was significant and the highest marketable bulb percentage $(93.24 \%)$ was recorded in $A_{1}$. Among the time of application, the highest marketable bulb percentage $(92.33 \%)$ was recorded in $\mathrm{B}_{1}$ and lowest marketable bulb percentage $(89.11 \%)$ recorded in $\mathrm{B}_{5}$. The interaction effect were non-significant, however the combination $\mathrm{A}_{1} \mathrm{~B}_{7}\left(\mathrm{~T}_{7}\right)$ recorded the maximum marketable bulb percentage $(94.64 \%)$. The minimum marketable bulb percentage (84.39 \%) recorded in $A_{3} B_{2}\left(T_{16}\right)$. From the foregoing results and discussion, it could be concluded as:

The foliar application of salicylic acid at lower concentration (100 $\mathrm{mg} / \mathrm{l})$ gives significantly maximum plant height, number of leaves per plant, total chlorophyll content, bulb diameter, average weight of bulb, total bulb yield, marketable bulb yield with significantly minimum purple blotch incidence and thrips incidence as compare to higher dose $(150 \mathrm{mg} / \mathrm{l})$ and water spray.

Foliar application of salicylic acid at 30 DAS during nursery stage and subsequently $2^{\text {nd }}$ spray at $30 \mathrm{DAT}, 3^{\text {rd }}$ spray at $45 \mathrm{DAT}$ and $4^{\text {th }}$ spray at 60 DAT during crop growth stage gives more growth, quality and yield parameters than single spray.

The combination $\mathrm{A}_{1} \mathrm{~B}_{7}\left(\mathrm{~T}_{7}\right)\left(1^{\text {st }}\right.$ spray of 250 $\mathrm{mg} / \mathrm{l}, 2^{\text {nd }}$ spray SA @ $100 \mathrm{mg} / \mathrm{lit}$ at 30 DAT, $3^{\text {rd }}$ spray SA@100 mg/lit at 45 DAT and $4^{\text {th }}$ spray @ $100 \mathrm{mg} / \mathrm{lit}$ at $60 \mathrm{DAT}$ ) not only recorded maximum growth parameters but also recorded the highest total bulb yield of 493.27 q ha- ${ }^{1}$ and marketable bulb percentage (94.64\%) with minimum storage losses.

Summing the present investigation, it can be concluded that, foliar application of SA as $1^{\text {st }}$ spray of $250 \mathrm{mg} / \mathrm{l}$ at 30 days after sowing in nursery stage, $2^{\text {nd }}$ spray SA @ $100 \mathrm{mg} / \mathrm{lit}$ at 30 DAT and $3^{\text {rd }}$ spray SA @ $100 \mathrm{mg} / \mathrm{lit}$ at 45 DAT and $4^{\text {th }}$ spray SA @ $100 \mathrm{mg} /$ lit at 60 DAT was found beneficial for obtaining maximum yield, quality and storability of onion.

\section{References}

Ahmad, M. A., Murali, P.V. and Marimuthu, G. 2013. Impact of salicylic acid on 
growth, photosynthesis and compatible solute accumulation in Allium cepa L. subjected to drought stress. ISSN: 22498516. Annamalai University, Tamil Nadu, India.

Amal, M., Shraiy, E. and Amira, M. H. 2009. Effect of acetylsalicylic acid, indole-3buytric acid and gibberellic acid on plant growth and yield of pea (Pisum Sativum L.). Australian J. Basic and App. Sci. 3(4): 3514-3523.

Amin, A. A., Rashad, E. M. and EL-Abagy H.M.H. 2007. Physiological effect of indole-3-butyric acid and salicylic acid on growth, yield and chemical constituents of onion plants. J. App. Sci. Res., 3(11): 1554-1563.

Anonymous, 2014. Indian Horticulture Database, Ministry of Agriculture, Government of India.

Anonymous, 2015. Annual Report of National Horticulture Reseasch and Development Foundation, Nashik (Maharashtra)

Barkosky, R. R., and Einhellig, F.A. 1993. Effects of salicylic acid on plant-water relationships. J. Chem. Ecol. 19(2): 237 $-47$.

Bideshki, A., and Arvin, M. 2010. Effect of salicylic acid (SA) and drought stress on growth, bulb yield and allicin content of garlic (Allium sativum L.) in field. $P l$. Ecophy. Iran. ISSN 2(2):73-79.

Chandra, A., Anand, A. and Dubey, A. 2007. Effect of salicylic acid on morphological and biochemical attributes in cowpea. J. Environ. Biol. 28(2): 193-196

Chandra, A., and Bhatt, R. K. 1998. Biochemical physiological response to salicylic acid in relation to the systemic acquired resistance. J. Photosynthetica. 35: 255-258.

Fariduddin, Q., Hayat, S. and Ahmad, A., 2003. Salicylic acid influences net photosynthetic rate, carboxylation efficiency, nitrate reductase activity and seed yield in Brassica juncea. Photosynthetica 41(2): 281-284.

Gharib, F.A., 2006. Effect of salicylic acid on the growth, metabolic activities and oil content of basil and marjoram. Int. J. Agril. Bio. 4: 485-492.

Gutierrez-Coronado, M. A., Trejo-Lopez, C. and Larque-Saavedra, A. 1998. Effects of salicylic acid on growth of roots and shoots in soybean. Pl. Physio. Biochem. 36: 653-665.

Helgi Opik S. and Rolfe A. 2005. The physiology of flowering plants. Cambridge Uni. Press. Pl. Physil: 191.

Ibrahim, I. S. and Sanaa, A. M. Z. 2005. Effects of naphthalene acetic acid, salicylic acid and midine on growth and bulbing of onion plant. Ann. Agril. Sci. 50(2):357-366.

Jain, A., Sbivastava, H. S. 1981. Effect of salicylic acid on nitrate reductase activity in maize seedlings. Physiol. Plant.51: 339-342.

Jeyakumar, P., Velu, G., Rajendran, C., Amutha, R., Savery, M.A. and Chidambaram, S. 2008. Varied responses of blackgram (Vigna munga) to certain foliar applied chemicals and plant growth regulators. Legume Res. Int. J. 31: 105-109.

Khodary, S.F., 2004. Effect of salicylic acid on the growth, photosynthesis and carbohydrate metabolism in salt stressed maize plants. Int. J. Agric. Biol. 6: 5-8.

Meena B., Arvindakshan K., Singh P., Yadav I. and Patidar, D. K. 2016. Effect of soaking and foliar application of salicylic acid and ethrel on growth, yield and biochemical traits of garlic (Allium sativum L) cv.G-282. Int. J. Farm Sci. 6(4): 61-66.

Pancheva, T.V., Popova, L.P. and Uzunova, A.M., 1996. Effect of salicylic acid on growth and photosynthesis in barley plants. J. Pl. Physiol. 149: 57-63.

Pancheva, T.V., Popova, L.P., 1998. Effect of 
salicylic acid on the synthesis of ribulose-1, 5-bisphosphate carboxylase /oxygenase in barley leaves. Plant Physiol. 152: 381-386.

Pankaj and Sharma H.K. 2003. Relative sensitivity of Meloidogyne incognita and Rotylenchulus reniformis to salicylic acid on okra. Indian $J$. Nematology. 33(2):120-123.

Panse, V.G. and Sukhatme, P.V. 1989. Statistical Methods for Agricultural Workers. ICAR, New Delhi.

Pradhan M., and Monalisa, 2014. Effect of salicylic acid on growth, yield, disease pest reaction and quality of onion. http://krishikosh.egranth.ac.in//1/94162.

Pradhan, M., Tripathy P., Mandal P., Sahoo B. B, Pradhan R., Mishra S. P. and Mishra H. N. 2016. Effect of Salicylic Acid on Growth and Bulb Yield of Onion (Allium Cepa L.) Int. J. Bioresource and Stress Manag. 7(4):960963.

Prajapati, S., Jain P.K. and Tiwari, A. 2016. Effects of Salicylic acid (SA) and Azospirillum on growth and bulb yield of Onion (Allium cepa L.) cv. Agrifound Light Red. Int. J. Agril. Environment and Biotechnology, IJAEB: 9(3): 393-402.

Raskin I. 1992. Role of salicylic acid in plants. Ann. Rev. Pl. Physiol. Plant Mol.
Biol. 43: 439-463

Sakhabutdinova, A. R., Fatkhutdinova, D. R., Bezrukova, M.V. and Shakirova, FM 2003. Salicylic acid prevents the damaging action of stress factors on wheat plants. Bulgarian J. Pl. Physiol. (special issue): 314-319.

Senaratna, T., Touchell, D. Bunn E. and Dixon K. 2000. Acetyl salicylic acid (Aspirin) and salicylic acid induce multiple stress tolerance in bean and tomato plants. Plant Growth Regul. 30: 157-161.

Shashikumar, H. M. and Shashidhar T.R. 2015. Effect of foliar application of growth regulators and bio-stimulant on growth and yield of onion var. Bhima Shakti. Indian J. Farm Sci. 29(1): 5052.

Sivakumar, R., Padmanaban, G., Kulkarani, M.K., Mallika, V. and Srinivasan, P.S. 2002. Effect of foliar application of growth regulators on biochemical attributes and grain yield in pearl millet. Indian J. Pl. Physiol. 7:79-82.

Yildirim, E. and Dursun A. 2009. Effect of foliar salicylic acid applications on plant growth and yield of tomato under greenhouse conditions. Ataturk University, Erzurum, Turkey. Acta Hort. 807.

\section{How to cite this article:}

Nangare S. B., S. D. Gaikwad, S. S. Dighe and Khamkar, M. B. 2018. Effect of Salicylic Acid on growth and yield of Onion (Allium cepa L.). Int.J.Curr.Microbiol.App.Sci. 7(06): 37413750. doi: https://doi.org/10.20546/ijcmas.2018.706.438 